\title{
Bay-scale assessment of eelgrass beds using sidescan and video
}

\author{
Herb Vandermeulen
}

Received: 2 April 2014/Revised: 13 August 2014/Accepted: 8 September 2014/Published online: 21 September 2014

(C) Her Majesty the Queen in Right of Canada 2014

\begin{abstract}
The assessment of the status of eelgrass (Zostera marina) beds at the bay-scale in turbid, shallow estuaries is problematic. The bay-scale assessment (i.e., tens of $\mathrm{km}$ ) of eelgrass beds usually involves remote sensing methods such as aerial photography or satellite imagery. These methods can fail if the water column is turbid, as is the case for many shallow estuaries on Canada's eastern seaboard. A novel towfish package was developed for the bay-scale assessment of eelgrass beds irrespective of water column turbidity. The towfish consisted of an underwater video camera with scaling lasers, sidescan sonar and a transponder-based positioning system. The towfish was deployed along predetermined transects in three northern New Brunswick estuaries. Maps were created of eelgrass cover and health (epiphyte load) and ancillary bottom features such as benthic algal growth, bacterial mats (Beggiatoa) and oysters. All three estuaries had accumulations of material reminiscent of the oomycete Leptomitus, although it was not positively identified in our study. Tabusintac held the most extensive eelgrass beds of the best health. Cocagne had the lowest scores for eelgrass health, while Bouctouche was slightly better. The towfish method proved to be cost effective and useful for the bayscale assessment of eelgrass beds to sub-meter precision in real time.
\end{abstract}

Keywords Estuary $\cdot$ Mapping $\cdot$ Seagrass $\cdot$ Sidescan

Communicated by F. Weinberger.

H. Vandermeulen $(\varangle)$

St. Andrews Biological Station, 531 Brandy Cove Rd.,

St. Andrews, NB E5B 2L9, Canada

e-mail: herb.vandermeulen@dfo-mpo.gc.ca

\section{Introduction}

The value of eelgrass (Zostera marina L.) in near-shore marine environments has come under close scrutiny in Canada over the last few years. Like other agencies in the northern hemisphere, Canada's federal Department of Fisheries and Oceans (DFO) has attempted to assess the available information on eelgrass and produce policy statements regarding its importance. The author was involved in this discussion and produced a number of assessment documents on the topic (Vandermeulen 2005; Vandermeulen et al. 2006; Vandermeulen 2009). Ultimately, the Science Branch of DFO designated eelgrass as an ecologically significant species (ESS, DFO 2009). The ESS designation recognizes the habitat value of eelgrass meadows-if a population of Z. marina were to be perturbed severely, the ecological consequences would be substantially greater than an equal perturbation of most other species associated with this community. Designating Z. marina as an ESS will aid in its protection in Canada (DFO 2009), and an attempt was made to quantify its response threshold to potential anthropogenic stressors (Vandermeulen et al. 2012).

As a part of the above exercise, DFO managers requested the assessment of eelgrass in various bays in northeastern New Brunswick. A question arose as to which method to use for this bay-scale mapping exercise, which operates at a scale of tens of $\mathrm{km}$. The most common method to map seagrasses at bay-scales worldwide has been to use aerial photography with ground truthing via underwater camera, snorkel, SCUBA or other direct visual observation (e.g., Kelly 1980; Short and Burdick 1996; McKenzie et al. 2001; Frederiksen et al. 2004; Leriche et al. 2004, 2006; Bernard et al. 2007). The method depends upon water clarity and this does place a limit on its 
ability to discern the depth limits of seagrass meadows in some situations. The depth limit can be as shallow as $4 \mathrm{~m}$ (Bernard et al. 2007).

Other remote sensing methods for seagrasses include satellite imagery (McKenzie et al. 2001; Gullstrom et al. 2006; Vela et al. 2008), the compact airborne spectrographic imager (CASI, Garono et al. 2004) or predictive models based upon LiDAR data (Valle et al. 2011). The results of these methods are also dependent upon water clarity (Vela et al. 2008; Barrell and Grant 2013) and water column optical properties, and Kirkman (1996) quite correctly states that 'Satellite images of underwater habitats are notoriously difficult to identify and interpret'. More recent analyses of this issue are no less critical (Shao and $\mathrm{Wu}$ 2008)

Others have also not been satisfied with aerial photography or other remote sensing methods for mapping eelgrass. Bekkby et al. (2008) suggest that aerial photography is not an optimal method for mapping and monitoring eelgrass along the west Norwegian coast because of wind and wave conditions and the sparse and patchy nature of Zostera in the region. They used a habitat distribution model fed by ground truth information collected by direct visual observation or an underwater camera.

Since remote sensing data must be ground truthed, it is logical to explore the merit of ground-truthing methods as independent mapping tools at bay-scales. If the groundtruthing method is cost effective and accurate at this scale, there is no need for the extra cost of additional remote sensing data and related analyses. Even basic ground-truthing observations by snorkel and SCUBA can have merit for independent evaluation of seagrass abundance on a scale of tens of $\mathrm{km}$ or more (Nienhuis et al. 1996; Hale et al. 2004). Stevens and Connolly (2005) used underwater videography to assess seagrass and other habitat features in an Australian bay covering approximately $1,500 \mathrm{~km}^{2}$.

In light of the above concerns, a novel towfish was developed for the bay-scale assessment of eelgrass beds irrespective of water column turbidity. The towfish consisted of an underwater video camera with scaling lasers, sidescan sonar and a sub-meter precision transponderbased positioning system. The intent was to use the sidescan imagery to determine bottom features on the basis of acoustic reflectivity and texture. Eelgrass makes a particularly good target for sidescan sonar as the air channels in its leaves (lacunae) are highly acoustically reflective. The video camera footage was used to ground truth the sidescan imagery and the transponder system ensured the accurate positioning of the towfish. The novelty of the design was that sidescan imagery, video ground truthing and positioning were all collected simultaneously in real time from the same towfish platform. All data were recorded for later analysis in the laboratory.

\section{Materials and methods}

Study sites

The three estuaries surveyed were Tabusintac, Bouctouche, and Cocagne on the northeastern coastline of the province of New Brunswick (Fig. 1). All three estuaries are known for their extensive eelgrass beds (Guy Robichaud, pers. comm.). The estuaries are shallow, with a large majority of bottom $2 \mathrm{~m}$ deep and drainage channels typically only 3-4 m deep. The mixed semidiurnal tides in these estuaries are rarely more than $1 \mathrm{~m}$. The bottom of these estuaries typically consists of soft mud, although some areas have firmer sand with shell hash. Rocky or cobble bottoms are rare and typically associated with drainage channels. The estuaries have rural watersheds consisting of a mix of forest and agricultural lands.

\section{Equipment}

The towfish system was described in Vandermeulen (2011). Briefly, all equipment was fitted to a 22' Cape Sable style custom wheelhouse research vessel (Rosborough Boats, Beechville, Nova Scotia, Canada) running 50 $\mathrm{hp}$ twin engines fitted with low pitch oversize propellers for maximum control at towing speeds (approximately 1.5 knots). Vessel and towfish positioning systems were fed by a Trimble (Sunnyvale, California, USA) $\operatorname{DSM}^{\mathrm{TM}} 132$ dGPS utilizing Canadian Coast Guard beacon differential signals (sub-meter precision). A $1 \mathrm{~kW}$ gas generator provided power for the electronics, which consisted of television and LCD monitors, sidescan and transceiver notebook computers, a video overlay (Horita Co. Inc., Mission Viejo, California, USA), a Shark Marine Technologies Inc. (St. Catharines, Ontario, Canada) SV-DV surface console (Sony miniDV tape deck and DC power generation for the SV-16 underwater video camera on the towfish), transceiver, scaling lasers $(650 \mathrm{~nm}, 7.5 \mathrm{~mW})$ and sidescan. The sidescan sonar was a SportScan (Imagenex Technology Corp., Port Coquitlam, British Columbia, Canada) set to $330 \mathrm{kHz}, 8 \mathrm{~dB}$ gain and $30 \mathrm{~m}$ swath width. The transponder/transceiver towfish positioning system was a TrackLink 1500LC (LinkQuest Inc., San Diego, California, USA). The battery powered transponder was clamped to the towfish frame, and the transceiver was bolted to the side of the vessel's hull.

The transceiver notebook computer was the heart of the positioning system for the towfish. It accepted feeds from the dGPS and a vessel-based digital compass (KVH Azimuth, Middletown, Rhode Island, USA) plus data from the transceiver. The output from the transceiver notebook computer was fed to the video overlay and to the notebook computer running the sidescan software. In this manner, 
Fig. 1 Locations of the three study estuaries, Tabusintac (T), Bouctouche (B) and Cocagne (C) on Canada's east coast.

Towfish transects indicated in black. Additional observations in Tabusintac as colored dots
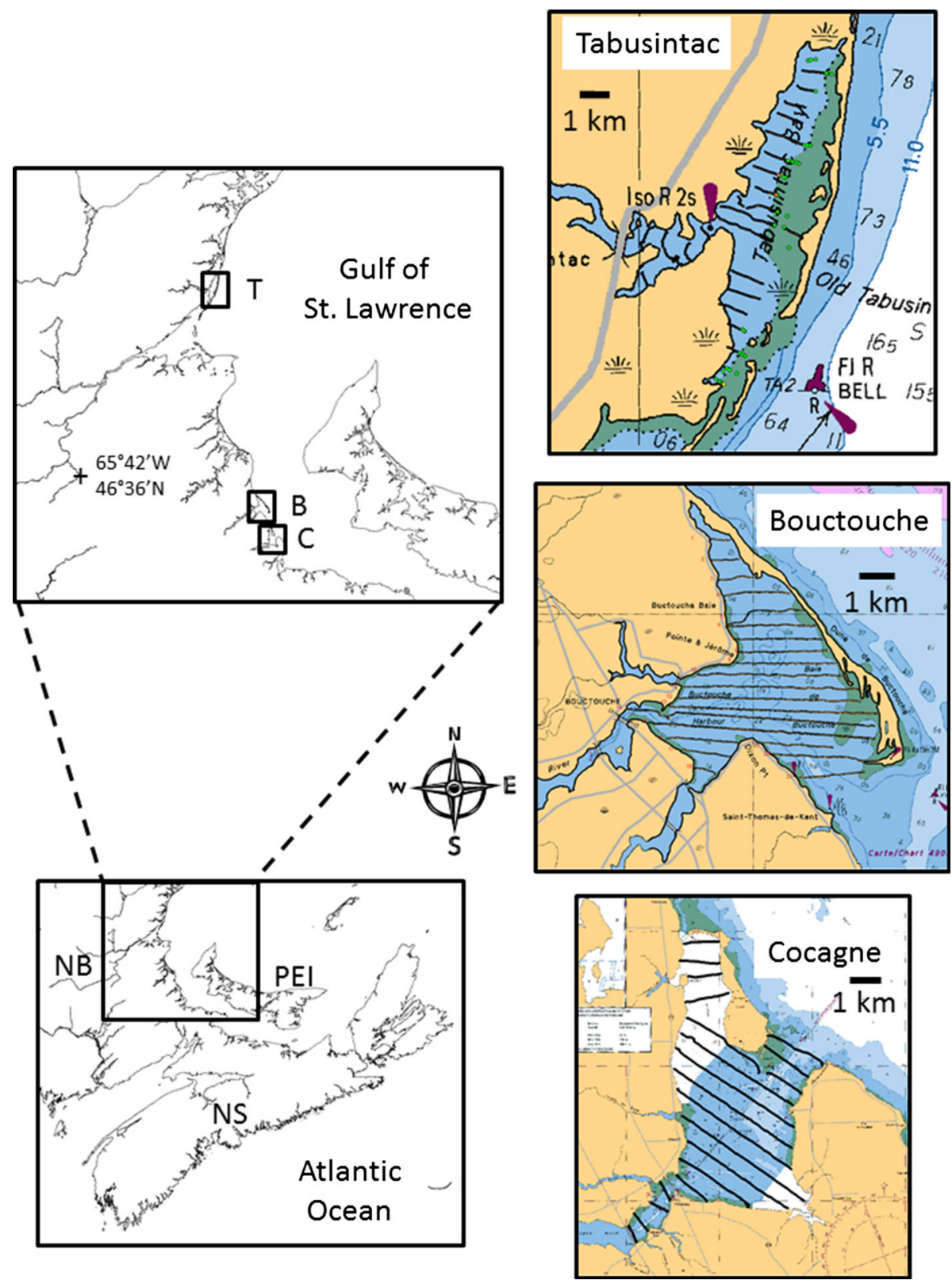

each frame of video and all sidescan data were linked to true towfish position in real time to sub-meter precision.

The $10 \mathrm{~cm}$ spacing of the lasers provided a scale for each frame of video. Typically, video frames encompassed approximately $1 \mathrm{~m}$ horizontal field of view comprising the midline or center of the sidescan swath of $30 \mathrm{~m}$, since the camera was mounted just below the sidescan on the towfish. The camera was mounted aiming forward and slightly downwards to get the best video for interpretation.

Field surveys

A three-person crew was required to operate the vessel and the electronics. Predetermined survey transects were marked on a navigation computer at the helm. From previous experience, it was known that 250-700 m transect spacing was adequate to capture significant bottom features on a bay-wide scale in similar areas in Atlantic Canada. For the present surveys, $400 \mathrm{~m}$ transect spacing was used (although this varied in the field as vessel course was corrected to avoid aquaculture sites and other obstacles). Transects were typically run perpendicular to shore, and the towfish was towed approximately $20 \mathrm{~cm}$ off the bottom, mediated by a clutch block and a deck hand holding the towfish cable steady. If the eelgrass was very dense, the towfish was held within the top one-third of the canopy, or about $60 \mathrm{~cm}$ off the bottom. In either case, the height of the sidescan relative to the bottom was enough to provide a full 
swath width. All transects were run during high tide as much as possible, although a survey could proceed with full swath width in waters as shallow as $1 \mathrm{~m}$. Cocagne was surveyed from July $17-19,2008$. The first attempt to survey Tabusintac occurred on August 2, 2008, but it was too windy and only a few transects were run. The Tabusintac survey was completed during August 19-22, 2008. The Bouctouche survey ran from August 20-24, 2009.

\section{Data processing}

The miniDV video tapes were post-processed into AVI video clips of approximately 10 min duration. The sidescan data were post-processed with SonarWizMAP sidescan mosaic software (Chesapeake Technology Inc., Mountain View, California, USA) to generate GeoTIFF image files. Both video clips and GeoTIFF image files were embedded into MapInfo GIS projects on external hard drives against bathymetric chart backgrounds. Each day of field survey turned into approximately 1.5-2 days of GIS processing by one person.

The basic unit of assessment for bottom features was the region of bottom covered by a single video clip along with the associated sidescan imagery. Each transect was numbered and each unit of assessment was given a letter designation in sequence along the associated transect. One person evaluated all units for all estuaries by examining each unit's video clip and sidescan data. That 'trained observer' performed a qualitative assessment for each unit by creating an average score or presence/absence judgement for the particular feature being assessed (eelgrass cover, oysters, etc.) in the unit. The resulting score for each feature was embedded into the GIS at the mid-point of the relevant assessment unit.

\section{Results}

Table 1 is a summary of field effort. The Cocagne and Bouctouche surveys went quite smoothly and approximately $13 \mathrm{~km}$ of sidescan data and over $4 \mathrm{~h}$ of video were collected per day. The Tabusintac survey was much more difficult due to inclement weather and the need to run only during peak high tides (the eastern side of this bay was very shallow, $<50 \mathrm{~cm}$ ). Only $5.3 \mathrm{~km}$ of sidescan data and $1.8 \mathrm{~h}$ of video were collected per day in Tabusintac.

The towfish transect positions are indicated in Fig. 1. The colored circles represent additional data points collected in Tabusintac in water too shallow for towfish use. The vessel was driven to these locations with the engines partially raised and a rough visual estimate of eelgrass percent cover was made over the side. In almost every instance $100 \%$ eelgrass cover was observed on the bottom,
Table 1 Summary of field effort

\begin{tabular}{llll}
\hline & Tabusintac & Bouctouche & Cocagne \\
\hline Survey time (days) & 5 & 5 & 3 \\
\# of transects & 26 & 21 & 20 \\
Total transect length $(\mathrm{km})$ & 26.4 & 66.0 & 39.4 \\
Hours of video collected & 8.73 & 23.12 & 13.08 \\
\hline
\end{tabular}

this is consistent with the very high eelgrass density observed in Tabusintac.

Figure 2 provides a selection of GeoTIFF images created from the sidescan data. Examples like these were used to classify bottom features along each transect. In Fig. 2a, the darker areas at either end represent acoustically nonreflective soft bottoms of low relief. The highly reflective area in the center of the image (arrow) is a harder bottom covered in shell hash. The pixelated vertical line in Fig. $2 b$ represents the $2 \mathrm{~m}$ mark; the water to the right of this line is quite shallow. The deeper water houses a dense continuous eelgrass bed (arrow 1). At the start of the shallows, the bed breaks up into a region of broad patches (arrow 2). The patches rapidly become smaller and less numerous, allowing the bare soft bottom to predominate (arrow 3). Figure $2 \mathrm{c}$ shows a flat soft bottom with occasional patches of eelgrass showing up as acoustically reflective areas (arrow). The highly textured three-dimensional pattern on the left side of Fig. $2 d$ is an oyster reef. The arrow indicates a crescent shaped ridge of oyster shells with a deep acoustic shadow behind it. The oyster reef has less relief in the center of the image and is replaced by a mud bottom (darker with less texture and relief) on the far right. Individual clusters of oyster start at the right of Fig. $2 \mathrm{e}$ on a soft bottom (arrow) and then build to the left into a solid oyster reef with intense acoustic reflectivity and texture.

The range of acoustic reflectivity, texture and relief expressed in the sidescan images was quite astounding. In most cases, it was possible to assess bottom features on the basis of this imagery alone. However, the video clip data were invaluable for ground-truthing purposes and provided definitive answers where the sidescan imagery was ambiguous. For example, bare hard-packed sand bottoms were almost indistinguishable from extensive eelgrass meadows in the sidescan images and the video clip data were required to distinguish between these two different features. Figure 3 provides examples of screenshots taken from various video clips for ground-truthing purposes and to identify bottom features. Figure $3 \mathrm{a}$ indicates dense, healthy eelgrass with snails (black dots). The image location is $47^{\circ} 23.2432^{\prime} \mathrm{N}, 64^{\circ} 54.9590^{\prime} \mathrm{W}$, taken on August 20, 2008. Figure $3 \mathrm{~b}$ shows spheres of 'Leptomitus'-like material. Grayish white mats of Beggiatoa (arrow) on a soft bottom are seen in Fig. 3c. Figure 3d 


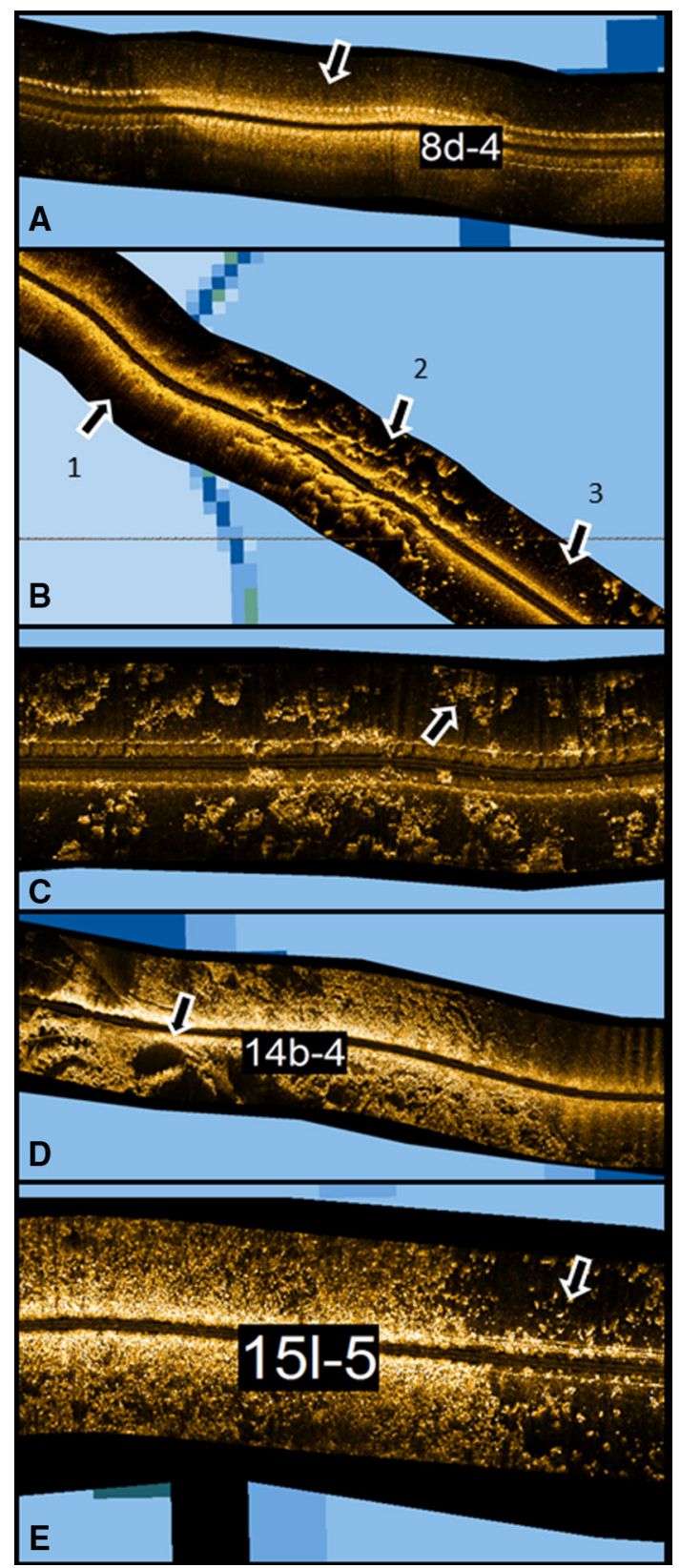

Fig. 2 Sidescan imagery from various sites in the bays, $30 \mathrm{~m}$ swath width in each instance. See text for explanations. a Bouctouche transect 8 in section D. b Cocagne transect 8 in section A. c Bouctouche transect 6 in section C. d Bouctouche transect 14 in section B. e Bouctouche transect 15 in section $\mathrm{L}$

shows a Beggiatoa mat (arrow) in a bare patch in an otherwise dense eelgrass bed. Eelgrass overgrown by filamentous green algae is seen in Fig. 3e. The resulting club-shaped object is characteristic (arrow). The water at this location is shallow $(<1 \mathrm{~m})$ and a portion of the transceiver arm can be seen in the upper right, covered in Ulva and other debris. Figure $3 \mathrm{f}$ shows clusters of oysters (arrows) on a soft bottom.
Assessment criteria for the cover and quality of the $Z$. marina beds in these bays are provided in Table 2 . The cover scores were generated by the sidescan data ground truthed by the video clips, while the quality scores were derived from the video clip data alone. It was not possible to estimate percent cover or shoot density within the Zostera beds with our data. The scores for each estuary are provided in Fig. 4, each score being placed in the midpoint of the associated assessment unit (some transect numbers are missing because a planned transect was not performed in the field due to shallow depths or other obstructions). Note that there was no consistent geographic pattern to these scores, other than the fact that inflow areas did not tend to have continuous, epiphyte free eelgrass beds. The lack of pattern is consistent with the rather homogenous bottom in these estuaries. Bottom relief was not highly variable, nor was bottom type.

There were differences between estuaries in terms of cover and quality scores for eelgrass; however. Table 3 is a compilation of the scores for each estuary. Tabusintac had a much higher proportion of continuous eelgrass meadow, or meadow with a few bare patches, compared to the other two estuaries. Cocagne has the poorest scores of all, with the highest proportion of eelgrass cover being represented by patchy clumps on a mud bottom. The cover scores were also reflected in the quality scores for the eelgrass in these estuaries. Tabusintac had a very high proportion of quality score 1 plants (luxurious eelgrass with low epiphyte load). It was also the only estuary with no areas with a quality score of 4 . In other words, live eelgrass or eelgrass remnants were found in every transect assessment unit. Consistent with its cover scores, Cocagne had the highest proportion of quality score 3 areasplants either completely covered in epiphytes or senescent (black or brown) or just eelgrass remnants with benthic algal mats.

Since bottom type was a rather uniform mud/sand of variable hardness, the rest of the assessment focused upon other bottom features. Oysters were found in each of the estuaries, most commonly associated with inflow areas or channels (Fig. 4). The species was most likely the eastern oyster (Crassostrea virginica Gmelin), which is also cultured locally in near-shore lease areas. The overgrowth of eelgrass blades by green filamentous algae was common in some of the near-shore areas in Bouctouche and Cocagne (Fig. 5). Characteristic gray-white benthic mats of the bacteria Beggiatoa were found in each estuary and particularly in Cocagne (Fig. 5). In the author's experience, these mats are typically associated with eutrophic (organic loading) conditions (Elliott et al. 2006; Kusel et al. 2006).

A rather odd bottom feature was discovered in the video clips. Dense accumulations of small sphere shaped objects were seen on some bottoms clear of other features or 

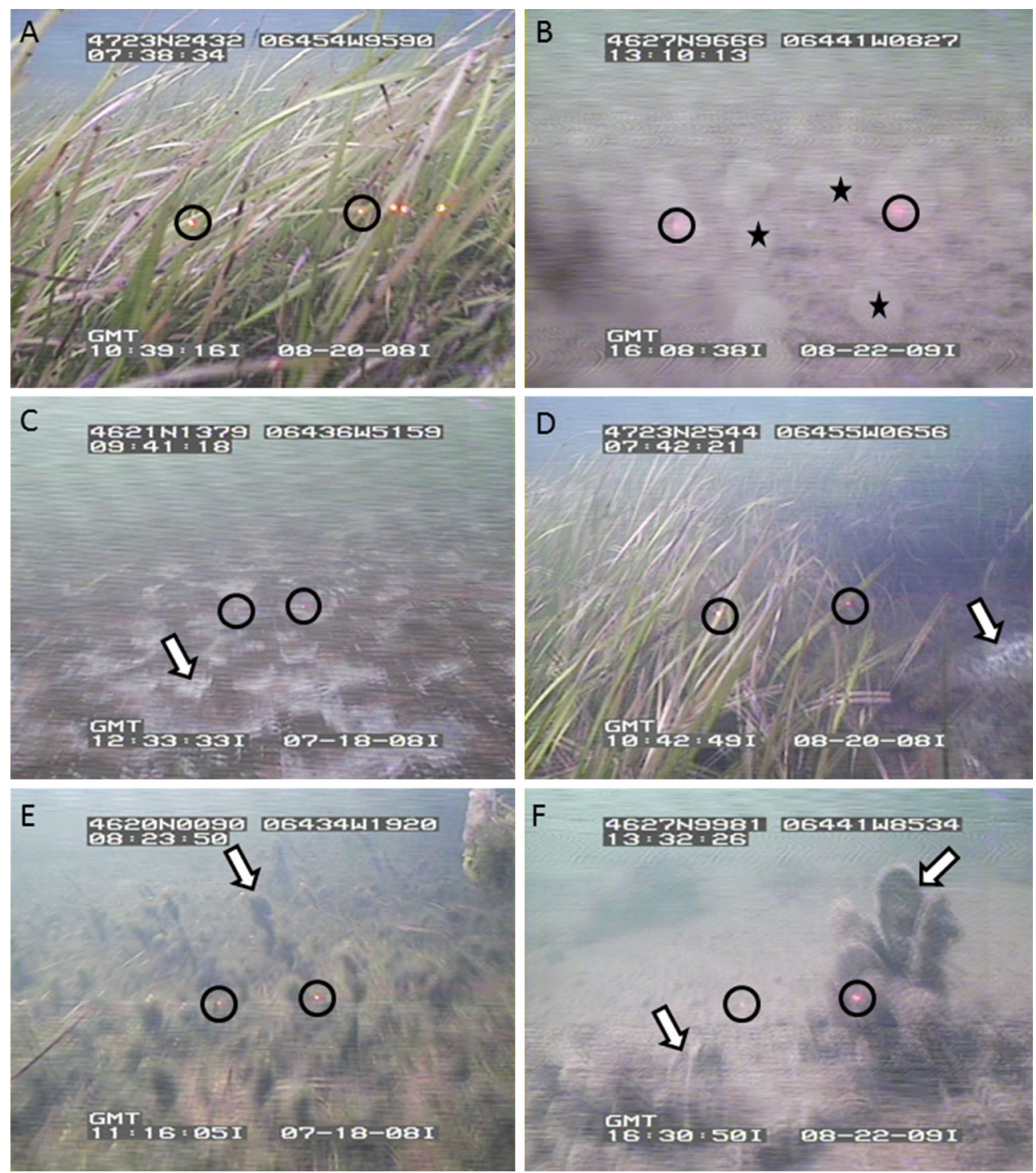

Fig. 3 Screenshots indicating various bottom features. The circles highlight the $10 \mathrm{~cm}$ laser scale. See text for explanations. a Tabusintac transect 2 in section A. b Bouctouche transect 16 in section C.

c Cocagne transect 13 in section $\mathrm{H}$. d Tabusintac transect 2 in section A. e Cocagne transect 13 in section A. f Bouctouche transect 16 in section $\mathrm{E}$

Table 2 Assessment criteria for the Z. marina beds

\begin{tabular}{|c|c|c|}
\hline Score & Cover & Quality \\
\hline 1 & Continuous bed & Green, luxurious eelgrass with very little or no epiphyte load (epigrazers common) \\
\hline 2 & Continuous bed with bare patches & Green leaves with medium to high density epiphyte load, leaves not pulled down by this load \\
\hline 3 & $\begin{array}{l}\text { Patches or clumps of leaves, no } \\
\text { continuous bed }\end{array}$ & $\begin{array}{l}\text { Epiphyte cover so high that no leaf surface is visible (bent over stunted/fragmented leaves covered in } \\
\text { algal material) OR majority of leaf surface is black or brown OR eelgrass remnants with the } \\
\text { presence of benthic algal mats }\end{array}$ \\
\hline 4 & No live eelgrass & No live eelgrass or eelgrass remnants \\
\hline
\end{tabular}

occasionally associated with thin clumps of eelgrass (Fig. 3b). The objects were most common in Bouctouche and Cocagne (Fig. 5). The objects were grayish white and easily disturbed by the towfish. They appeared to have the texture of small balls of cotton. The most likely candidate for this bottom feature is the oomycete Leptomitus, which 


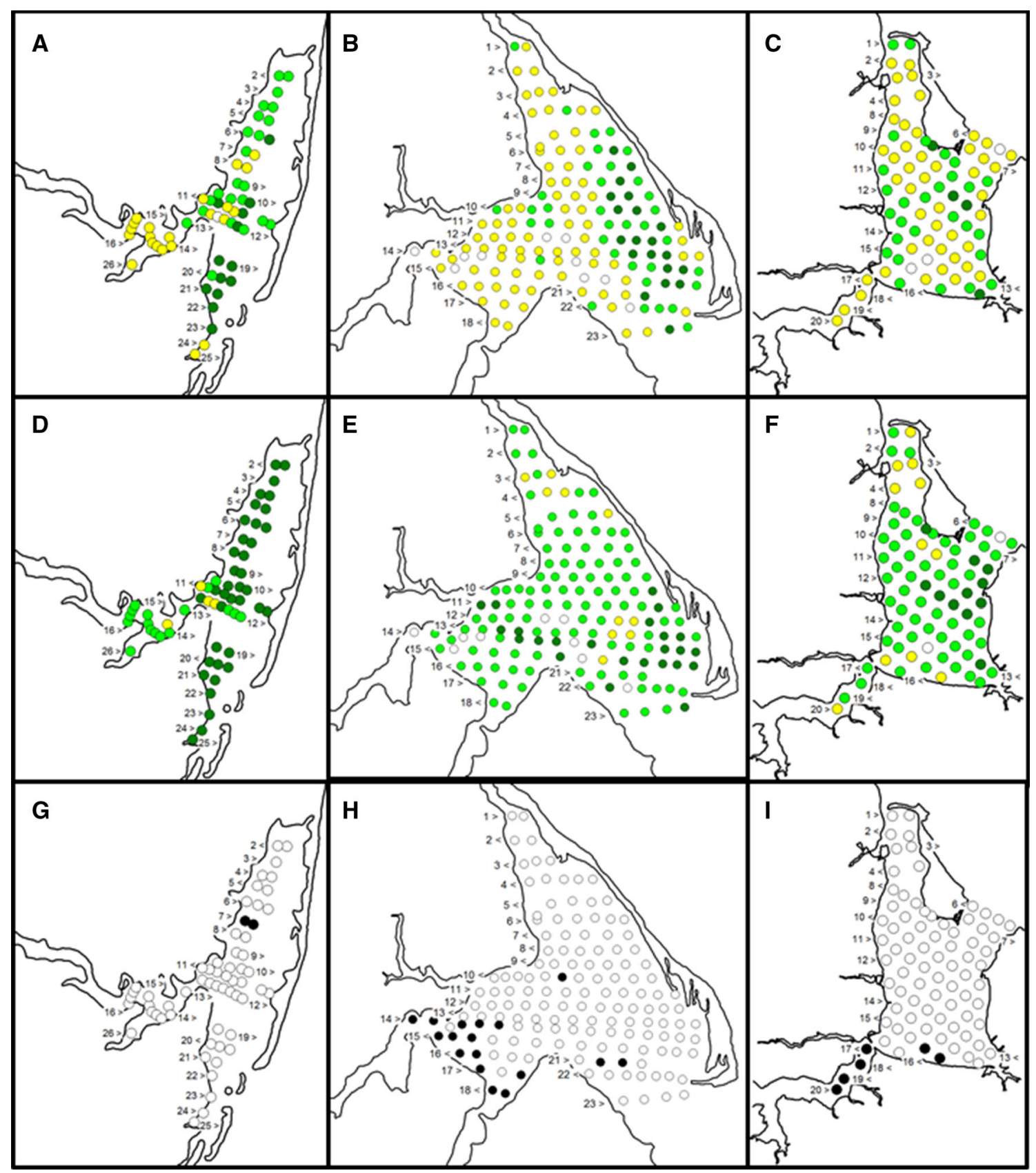

Fig. 4 Bottom feature maps. Left column Tabusintac, middle column Bouctouche, and right column Cocagne. Transect numbers indicate direction of tow ( $\leq$ to the west, $\geq$ to the east). a-c Eelgrass cover

is associated with sources of organic carbon loading such as drainage from cattle farms (Tom Booth, pers. comm.). Although Leptomitus is typically associated with freshwaters, it can occur in more saline environments in Canada (Tom Booth, pers. comm.). The term 'Leptomitus'-like objects is used here, as it was not possible to obtain a positive taxonomic identification. scores. $1=$ dark green circles, $2=$ light green circles, $3=$ yellow circles, $4=$ white circles. $\mathbf{d}-\mathbf{f}$ Eelgrass quality scores. $\mathbf{g}-\mathbf{i}$ Oysters. Present $=$ black circles, absent $=$ white circles

\section{Discussion and conclusion}

Utility of the fused video/sidescan survey system at bay-scales

The concept of scale is crucial for the study of landscape ecology as applied to estuaries and to the application of 
DFO science advice in these bodies of water. Hovel et al. (2002) provide an interesting discussion on the issue of scale for mapping and assessing seagrass beds. They consider information collected at $<1-10 \mathrm{~s}$ of $\mathrm{m}$ as the local scale and data collected at 100-1,000 s of $\mathrm{m}$ as the landscape scale. In that light, the bay-scale is the landscape scale. Neckles et al. (2012) formalized the concept of seagrass monitoring across different spatial scales and sampling intensities. They applied a system of three tiers of monitoring. Tier 1 monitoring is applied at large spatial scales, typically using remote sensing methods. Tier 2 monitoring examines specific properties (e.g., percent cover) at a higher resolution over large geographic areas (e.g., bay-scale) generally using ground-based approaches. Tier 3 monitoring examines a greater number of properties or responses (e.g., shoot density, biomass) at a smaller number of locations with greater intensity. In this context, our survey of the three New Brunswick bays was a tier 2 exercise.

Fonseca et al. (2002) utilized a towed camera system accurately positioned by post-processing of GPS data to assess eelgrass cover at a landscape scale. The field of view of their camera was $1 \mathrm{~m}$, similar to our system. Their video transects were sometimes more than a kilometer long, similar to the scale of effort attempted here. Fonseca et al. (2002) concluded that video sampling at this scale may be an effective method of detecting changes in seagrass cover arising from anthropogenic disturbance. This is consistent with the level of information expected from tier 2 monitoring exercises (Neckles et al. 2012).

Our system has built upon the Fonseca et al. (2002) methods by expanding the $1 \mathrm{~m}$ video field of view to a $30 \mathrm{~m}$ sidescan field of view. In this manner, the bottom features seen within the video can be confidently assessed in an area 30 times greater. Since this all occurs in real time, ground truthing is extensive and there is no secondguessing temporal change in eelgrass cover due to performing a sidescan survey at one point of time and ground truthing by video or other methods at another point in time. To the author's knowledge, no other researchers have fused video and sidescan hardware into one towfish for shallow water use. In other sidescan surveys of seagrasses, the sidescan portion of the survey was done independently of the ground-truthing portion which was usually more limited in aerial extent (e.g., Mulhearn 2001; Leriche et al. 2004, 2006; Montefalcone et al. 2006; Kiparissis et al. 2011; Oakley et al. 2012; Sánchez-Carnero et al. 2012). Montefalcone et al. (2013) particularly stressed the requirement for well-designed and extensive ground truthing for the interpretation of sidescan sonograms from seagrass meadows.

Furthermore, the fused video and sidescan towfish survey method dispenses with the requirement for remote sensing data at bay-scales (i.e., tens of $\mathrm{km}$ ). The additional expense of the remote sensing data is not necessary. The author has also seen remote sensing methods fail in similar bays due to turbidity in waters as shallow as $4 \mathrm{~m}$.

An assessment of the three estuaries

The towfish data were adequate to discern major bottom features at the bay-scale to sub-meter precision in real time. These features included eelgrass, oysters, Beggiatoa mats, and the presence of a 'Leptomitus'-like growth. Since video footage was collected along every meter of towfish transect, it was also possible to assess the epiphyte load upon the eelgrass.

Although physical factors such as wind and wave exposure can alter the cover of eelgrass in particular locations (Fonseca and Bell 1998), it is more likely that the differences seen in the three New Brunswick estuaries were due to anthropogenic impacts. Zostera marina cover scores were tied to quality scores in these estuaries, suggesting that cover was being influenced by epiphyte load or other impacts of eutrophication. Cocagne provided the best evidence for this hypothesis. Beggiatoa was present in all three estuaries, particularly in Cocagne (Fig. 5). The greater abundance of Beggiatoa in Cocagne is consistent with the poorer scores for eelgrass cover and quality in that particular estuary (Table 3). The presence of benthic Beggiatoa mats indicates anthropogenic organic enrichment which alters sediment quality to a state not conducive to eelgrass growth (Elliott et al. 2006). The suspected presence of organically polluted water in Cocagne is also consistent with the abundance of 'Leptomitus'-like material in that particular estuary (Taylor et al. 2009). Cocagne also had extensive overgrowth of eelgrass due to

Table 3 Zostera cover and quality scores for each estuary

\begin{tabular}{lll}
\hline Estuary & $\begin{array}{l}\text { Cover } \\
\text { Score-\# of points-\% of } \\
\text { points }\end{array}$ & $\begin{array}{l}\text { Quality } \\
\text { Score-\# of points-\% of } \\
\text { points }\end{array}$ \\
\hline Tabusintac & $1-13-22.0$ & $1-38-64.4$ \\
& $2-23-39.0$ & $2-17-28.8$ \\
& $3-22-37.3$ & $3-4-6.8$ \\
& $4-1-1.7$ & $4-0-0$ \\
Bouctouche & $1-20-13.6$ & $1-24-16.3$ \\
& $2-36-24.5$ & $2-104-70.7$ \\
& $3-81-55.1$ & $3-10-6.8$ \\
Cocagne & $4-10-6.8$ & $4-9-6.1$ \\
& $1-4-4.9$ & $1-11-13.6$ \\
& $2-28-34.6$ & $2-57-70.4$ \\
& $3-46-56.8$ & $3-11-13.6$ \\
& $4-3-3.7$ & $4-2-2.5$ \\
\hline
\end{tabular}




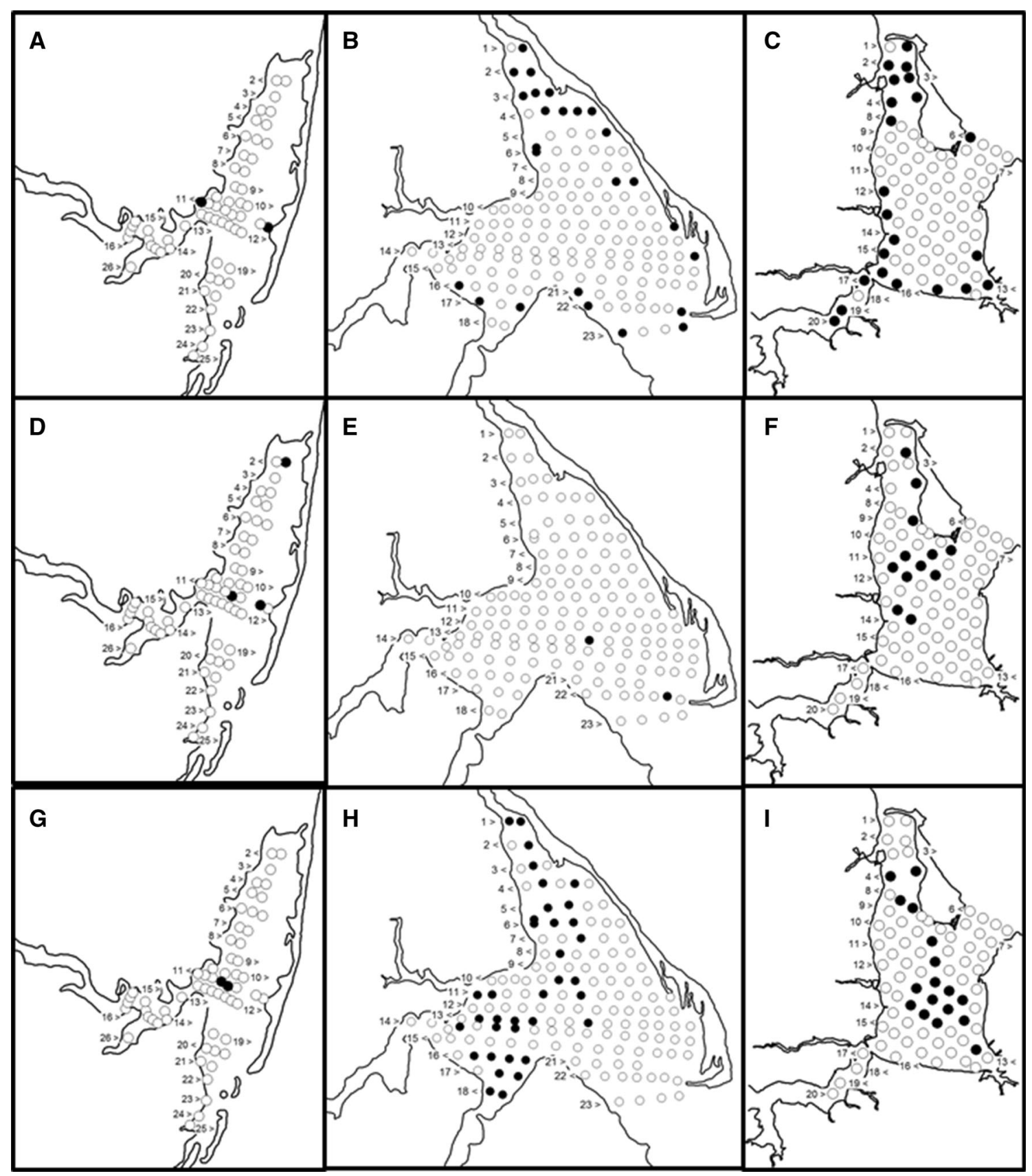

Fig. 5 Bottom feature maps. Columns and transect numbers as in Fig. 4. Present $=$ black circles, absent $=$ white circles. a-c Overgrowth by green filamentous algae. d-f Beggiatoa. $\mathbf{g - i}$ 'Leptomitus'-like objects

filamentous green algal epiphyte cover in the shallows near-shore. This is indicative of nutrient-based eutrophication (Vandermeulen et al. 2012).

Oyster mariculture is quite common along the northeastern shore of New Brunswick, and the ability of the towfish to discern natural oyster reefs has management implications. The oyster reefs occurred primarily along the edges of channels which are also used for vessel traffic. Since these channels are shallow, there is the potential for vessel impacts upon the oyster reefs. Towfish data could be used to discern these impacts. Sidescan sonar imagery has been successful in discerning oyster and serpulid reefs and associated anthropogenic impacts in shallow waters (Moore et al. 2009; van Overmeeren et al. 2009; Raineault et al. 2012).

This study has demonstrated equipment and methods capable of elucidating eelgrass cover and heath, plus other bottom features, on bay-wide scales at relatively moderate 
costs. Future applications will include assessing commercial seaweed abundance and aquaculture impacts on similar scales.

Acknowledgments Field assistance was provided by Carole Godin, Marc Godin, Al Hanson, Brian Jones, Venitia Joseph, Carole LeBlanc, Jean-Claude Legresley, Ray MacIsaac, Matthew Mahoney, Jean-Francois Mallet, Guy Robichaud, Fernand Savoie and Anne Turcotte. Megan Wilson and Brian Jones created the baseline GIS projects.

\section{References}

Barrell J, Grant J (2013) Detecting hot and cold spots in a seagrass landscape using local indicators of spatial association. Landsc Ecol 28:2005-2018

Bekkby T, Rinde E, Erikstad L, Bakkestuen V, Longva O, Christensen O, Isaeus M, Isachsen PE (2008) Spatial probability modelling of eelgrass (Zostera marina) distribution on the west coast of Norway. ICES J Mar Sci 65:1093-1101

Bernard G, Boudouresque CF, Picon P (2007) Long term changes in Zostera meadows in the Berre lagoon (Provence, Mediterranean Sea). Estuar Coast Shelf S 73:617-629

DFO (2009) Does eelgrass (Zostera marina) meet the criteria as an ecologically significant species? Fisheries and Oceans, Canadian Science Advisory Secretariat, Science Advisory Report 2009/018, p 11. http://www.dfo-mpo.gc.ca/csas-sccs/publica tions/sar-as/2009/2009_018-eng.htm

Elliott JK, Spear E, Wyllie-Echeverria S (2006) Mats of Beggiatoa bacteria reveal that organic pollution from lumber mills inhibits growth of Zostera marina. Mar Ecol 27:372-380

Fonseca MS, Bell SS (1998) Influence of physical setting on seagrass landscapes near Beaufort, North Carolina, USA. Mar Ecol Prog Ser 171:109-121

Fonseca M, Whitfield PE, Kelly NM, Bell SS (2002) Modeling seagrass landscape pattern and associated ecological attributes. Ecol Appl 12:218-237

Frederiksen M, Krause-Jensen D, Holmer M, Laursen JS (2004) Long-term changes in area distribution of eelgrass (Zostera marina) in Danish coastal waters. Aquat Bot 78:167-181

Garono RJ, Simenstad CA, Robinson R, Ripley H (2004) Using high spatial resolution hyperspectral imagery to map intertidal habitat structure in Hood Canal, Washington, USA. Can J Remote Sens 30:54-83

Gullstrom M, Lunden B, Bodin M, Kangwe J, Ohman MC, Mtolera MSP, Bjork M (2006) Assessment of changes in the seagrassdominated submerged vegetation of tropical Chwaka Bay (Zanzibar) using satellite remote sensing. Estuar Coast Shelf S 67:399-408

Hale JA, Frazer TK, Tomasko DA, Hall MO (2004) Changes in the distribution of seagrass species along Florida's central Gulf Coast: Iverson and Bittaker revisited. Estuaries 27:36-43

Hovel KA, Fonseca MS, Myer DL, Kenworthy WJ, Whitfield PE (2002) Effects of seagrass landscape structure, structural complexity and hydrodynamic regime on macrofaunal densities in North Carolina seagrass beds. Mar Ecol Prog Ser 243:11-24

Kelly MG (1980) Remote sensing of seagrass beds. In: Phillips RC, McRoy CP (eds) Handbook of seagrass biology: an ecosystem perspective. Garland STPM Press, New York, pp 69-85

Kiparissis S, Fakiris E, Papatheodorou G, Geraga M, Kornaros M, Kapareliotis A, Ferentinos G (2011) Illegal trawling and induced invasive algal spread as collaborative factors in a Posidonia oceanica meadow degradation. Biol Invasions 13:669-678
Kirkman H (1996) Baseline and monitoring methods for seagrass meadows. J Environ Manage 47:191-201

Kusel K, Trinkwalter T, Drake HL, Devereux R (2006) Comparative evaluation of anaerobic bacterial communities associated with roots of submerged macrophytes growing in marine or brackish water sediments. J Exp Mar Biol Ecol 337:49-58

Leriche A, Boudouresque CF, Bernard G, Bonhomme P, Denis J (2004) A one-century suite of seagrass bed maps: can we trust ancient maps? Estuar Coast Shelf S 59:353-362

Leriche A, Pasqualini V, Boudouresque CF, Bernard G, Bonhomme P, Clabaut P, Denis J (2006) Spatial, temporal and structural variations of a Posidonia oceanica seagrass meadow facing human activities. Aquat Bot 84:287-293

McKenzie LJ, Finkbeiner MA, Kirkman H (2001) Methods for mapping seagrass distribution. In: Short FT, Coles RG (eds) Global seagrass research methods. Elsevier Science B.V., Amsterdam, pp 101-121

Montefalcone M, Albertelli G, Bianchi CN, Mariani M, Morri C (2006) A new synthetic index and a protocol for monitoring the status of Posidonia oceanica meadows: a case study at Sanremo (Ligurian Sea, NW Mediterranean). Aquat Conserv 16:29-42

Montefalcone M, Rovere A, Parravicini V, Albertelli G, Morri C, Bianchi CN (2013) Evaluating change in seagrass meadows: a time-framed comparison of side scan sonar maps. Aquat Bot 104:204-212

Moore CG, Bates CR, Mair JM, Saunders GR, Harries DB, Lyndon AR (2009) Mapping serpulid worm reefs (Polychaeta: Serpulidae) for conservation management. Aquat Conserv 19:226-236

Mulhearn PJ (2001) Mapping seabed vegetation with sidescan sonar. Australian Department of Defence, Defence Science and Technology Organisation, Aeronautical and Maritime Research Laboratory. DSTO-TN-0381. p 28. http://www.dtic.mil/cgi-bin/ GetTRDoc?AD=ADA395552

Neckles HA, Kopp BS, Peterson BJ, Pooler PS (2012) Integrating scales of seagrass monitoring to meet conservation needs. Estuar Coast 35:23-46

Nienhuis PH, De Bree BHH, Herman PMJ, Holland AMB, Verschuure JM, Wessel EGJ (1996) Twenty-five years of changes in the distribution and biomass of eelgrass, Zostera marina, in Grevelingen Lagoon, The Netherlands. Neth $J$ Aquat Ecol 30:107-117

Oakley BA, Alvarez JD, Boothroyd JC (2012) Benthic geologic habitats of shallow estuarine environments: Greenwich Bay and Wickford Harbor, Narragansett Bay, Rhode Island, USA. J Coast Res 28:760-773

Raineault NA, Trembanis AC, Miller DC (2012) Mapping benthic habitats in Delaware Bay and the coastal Atlantic: acoustic techniques provide greater coverage and high resolution in complex, shallow-water environments. Estuar Coast 35:682-699

Sánchez-Carnero N, Rodríguez-Pérez D, Couñago E, Aceñaand S, Freire J (2012) Using vertical sidescan sonar as a tool for seagrass cartography. Estuar Coast Shelf S 115:334-344

Shao G, Wu J (2008) On the accuracy of landscape pattern analysis using remote sensing data. Landsc Ecol 23:505-511

Short FT, Burdick DM (1996) Quantifying eelgrass habitat loss in relation to housing development and nitrogen loading in Waquoit Bay, Massachusetts. Estuaries 19:730-739

Stevens T, Connolly RM (2005) Local-scale mapping of benthic habitats to assess representation in a marine protected area. Mar Freshw Res 56:111-123

Taylor BR, Garbary DJ, Miller A, Bärlocher F (2009) Metabolism and ecology of the water mould, Leptomitus lacteus (Oomycota), blooming in winter in a Nova Scotia stream. Fundam Appl Limnol 175:171-180

Valle M, Borja A, Chust G, Galparsoro I, Garmendia JM (2011) Modelling suitable estuarine habitats for Zostera noltii, using 
ecological niche factor analysis and bathymetric LiDAR. Estuar Coast Shelf S 94:144-154

van Overmeeren R, Craeymeersch J, van Dalfsen J, Fey F, van Heteren S, Meesters E (2009) Acoustic habitat and shellfish mapping and monitoring in shallow coastal water-sidescan sonar experiences in The Netherlands. Estuar Coast Shelf S $85: 437-448$

Vandermeulen H (2005) Assessing marine habitat sensitivity: a case study with eelgrass (Zostera marina L.) and kelps (Laminaria, Macrocystis). Fisheries and Oceans, Canadian Science Advisory Secretariat, Research Document 2005/032, p 57. http://www.dfompo.gc.ca/csas-sccs/publications/resdocs-docrech/2005/2005_032eng.htm

Vandermeulen H (2009) An introduction to eelgrass (Zostera marina L.): the persistent ecosystem engineer. Fisheries and Oceans, Canadian Science Advisory Secretariat, Research Document 2009/085, p 11. http://www.dfo-mpo.gc.ca/csas-sccs/publica tions/resdocs-docrech/2009/2009_085-eng.htm
Vandermeulen H (2011) Mapping the nearshore using a unique towfish. Canadian Technical Report of Fisheries and Aquatic Sciences 2959, p 18. http://www.dfo-mpo.gc.ca/Library/344627.pdf

Vandermeulen H, Jamieson G, Ouellette M (2006) Shellfish aquaculture and marine habitat sensitivity case studies. Fisheries and Oceans, Canadian Science Advisory Secretariat, Research Document 2006/036, p 62. http://www.dfo-mpo.gc.ca/csas-sccs/ publications/resdocs-docrech/2006/2006_036-eng.htm

Vandermeulen H, Surette J, Skinner M (2012) Responses of eelgrass (Zostera marina L.) to stress. Fisheries and Oceans, Canadian Science Advisory Secretariat, Research Document 2011/095, p 43. http://www.dfo-mpo.gc.ca/csas-sccs/Publications/ResDocs-Doc Rech/2011/2011_095-eng.html

Vela A, Pasqualini V, Leoni V, Djelouli A, Langar H, Pergent G, PergentMartini C, Ferrat L, Ridha M, Djabou H (2008) Use of SPOT 5 and IKONOS imagery for mapping biocenoses in a Tunisian Coastal Lagoon (Mediterranean Sea). Estuar Coast Shelf S 79:591-598 